\title{
What Role for Activation in Eco-Social Policy?
}

\section{Fiona Dukelow}

\author{
University College, Cork, Ireland.
}

E-mail: f.dukelow@ucc.ie

This article aims to bring labour market activation policy into the orbit of eco-social policy, which we can understand as sustainable welfare without growth. Activation is extensively addressed from economic and social policy perspectives; however, environmental sustainability concerns are absent. Typically, each domain, activation and sustainability, is seen as mutually exclusive. Growing debate about sustainable welfare without growth features much discussion about the effects of productivism and about re-orienting and re-valuing work and how we use our time; however, such discussion tends to leave activation and unemployment untouched. One could ask whether there is any role for activation in eco-social policy: why focus on employment and employability, or even push people into work, if postgrowth requires a downsizing of paid employment and working time in everyone's lives? The purpose of this article is to explore this question and to consider how activation could be re-valued and re-thought as a policy tool for eco-social policy.

Keywords: Activation, eco-social policy, post-growth, job guarantee, sustainable welfare.

\section{Introduction}

This article aims to bring labour market activation policy into the orbit of eco-social policy, which we can understand as sustainable welfare without growth (Koch, 2018). Activation is extensively addressed from economic and social policy perspectives; however, environmental sustainability concerns are absent. Typically each domain, activation and sustainability, is seen as mutually exclusive (Aigner et al., 2016). Moreover, the direction in which activation policies in many jurisdictions are travelling, becoming more demanding, coercive and work-first focused, increases this disconnect by contributing to the growth of precarious employment, and unequal and unsustainable economies. Sustainable welfare without growth, whether we describe this as postgrowth or degrowth, is understood 'as an equitable and democratic transition to a smaller economy with less production and less consumption' (Martínez-Alier et al., 2010: 1741). This transition is both urgent and challenging. Gough (2017: 15) notes that degrowth 'is incompatible with the accumulation drive of any form of capitalism yet is ultimately - and quite soon - essential for our future prosperity, if not our very existence'. Growing debate about sustainable welfare without growth features much discussion about the effects of productivism and about re-orienting and re-valuing work and how we use our time; however, such discussion tends to leave activation untouched. One could ask whether there is any role for activation in eco-social policy: why focus on employment 
and employability, or even push people into work, if postgrowth requires a downsizing of paid employment and working time in everyone's lives?

The purpose of this article is to explore this question and to consider how activation could be re-valued and re-thought as a policy tool for eco-social policy. It does this in two parts. It begins by briefly surveying the evolution of activation policy. Specifically it highlights socially oriented iterations of activation policy which had their roots in responses to structural unemployment, and which focused on activation as social inclusion and job creation. In this regard such types of work came closer to understandings and definitions of work that both critique and extend beyond work as paid employment to work as 'what gets done to make life possible' (Pettinger, 2019: 5). In other words, the tasks and activities carried out to ensure social reproduction, care and maintenance of ourselves and our communities. While this type of activation programme has been in long-term decline and is deemed detrimental for re-integrating people into the labour market, this article considers how such work could connect to discussions and proposals about work in postgrowth debate and what shape activation as job creation might take in a postgrowth welfare state. The article follows this train of thinking by switching from discussion of activation to looking at work and proposals for work in postgrowth thinking. This second part therefore traverses some of the heterogeneous terrain and discussions of good or sustainable discussion of work in postgrowth thinking. It thinks through what role, if any, activation would have in these alternative ways of looking at work and progressing sustainable welfare and considers the connections between activation as job creation and a postgrowth job guarantee.

\section{The evolution of activation and the demise of job creation}

Work, and lack of work took centre stage in the plans that animated discussions for how welfare states should evolve post-world war two. Not least in the Beveridge Report where lack of work, or 'idleness,' was one of the five giants to be slayed. Whereas campaigns for less work and the institution of a five-day working week were defining features of discussion and the developments in response to the recessionary 1930s (Kallis et al., 2013), by the 1950s, the achievement of full (male) employment was a core policy ambition. As part of this, active labour market policy played a key role in the welfare state. In its early iteration this involved re-fitting and up-skilling labour for major shifts in industry which were both a cause of unemployment and a source of labour shortages that such policy aimed to address (Bonoli, 2011).

By the 1980s the rationale for active labour market policy tilted more to the social. As such, there was as much of a social as an economic response to unemployment, in order to keep people occupied and to maintain social cohesion rather than re-integration into the labour market (Bonoli, 2011). This acknowledged the fact that, after the 1970s economic crisis, welfare states faced large waves of unemployment, including long-term and youth unemployment. At this point therefore, job creation, also known as direct employment or public sector employment, and which provided employment related to the provision of public goods and services, grew as a core feature of labour market policy. It featured heavily in some continental welfare states, and in the Nordic states. In 1985, for example, Sweden spent .29 per cent of GDP on job creation and Germany .10 of GDP (OECD, 1994). Related measures included: early retirement schemes to allow people to exit the labour market early; other forms of job 
creation such as sheltered employment; and public subsidisation of privately provided employment.

The much mentioned 'activation turn' of the 1990s saw a shift away from this policy ethos and a turn against direct job creation. While the welfare state, unemployment and labour market policy have always had a productivist orientation, the activation turn took on what could be called hyper-productivism evident in pivotal OECD and EU thinking. The OECD in its Jobs Study (1994) took a more typically neo-liberal view of activation, seeing 'passive benefits' as an economic drain. The EU response, as active inclusion institutionalised by the European Employment Strategy in 1997, sought to combine 'old' and 'new' forms of activation to enhance productivity, employability and economic growth (Weishaupt, 2013).

Regardless of the differences in thinking about labour market policy and the welfare state, the effect of both strands was to emphasise the importance of drawing all adults into the labour market, with employment or at least employability considered the defining characteristic of all adults. In the context of a return to economic growth and rising labour shortages, labour market policy turned to 'activate' those not attached or marginally attached to the labour market, especially low-skilled adults. Attention shifted to strengthening work incentives, either positively or negatively, and to the much closer integration of income maintenance with labour activation measures. Understandings of welfare and the relationship between welfare and work evolved as a result. As Weishaupt (2013: 190, 192) puts it, 'the underlying assumption is that full citizenship can only be reinstituted through (forced) labour market integration of the "able-bodied"'. Moreover, 'a particular socio-economic logic has been introduced, namely that economic activity is a necessary condition for individual self-fulfilment, the sustainability of welfare states and overall economic competitiveness'. Activation thus became fully part of the treadmill of growth and jobs: growth is needed to generate work, work is needed to generate growth (Hoffmann and Paulsen, 2020; Wiese and Mayrhofer, 2020).

Underpinning these changes were evolving assumptions about work and the work ethic. Activation, as part of the assemblage of value articulating institutions that make up the welfare state, plays a key role in the value placed on work and the devaluing of those without work (Sage, 2019). Activation thus became a vehicle for the intensification of the work ethic under neoliberalism which involves a condemnation of laziness, the idealisation of 'hard work', and the 'moral fortification of work' (Hoffmann and Paulsen, 2020: 348). In this context, activation itself became a form of work and display of one's work ethic. This is akin to what Standing (2011: 48) calls 'work for labour' with the unemployed having 'multiple "workplaces"- employment exchanges, benefit offices, job-search training offices'. This 'work for labour' centres on testing the work ethic of the unemployed, their motivation, their willingness to be at the disposal of the labour market, which are dispositions cultivated under coercive conditions.

In the round then, reforms since the 1990s involved almost all European countries tightening several aspects of activation practice including: the monitoring of people in receipt of welfare; the requirements around reporting job search activities; obligations to take up activation or work offers; and what constitutes a suitable job offer. Early exit options were also gradually closed. Many of these reforms were informed by a growing body of econometric studies, focusing on 'what works' in terms of labour market outcomes. Direct job creation specifically was subject to a series of negative evaluations for being costly, inefficient, for creating deadweight, for fostering 'programme careers' 
(Dengler, 2015), and ultimately for not leading to employment in the open labour market. In short, the productivist credentials of job creation as activation were found lacking. From scepticism about their benefits in 'first generation' econometric studies undertaken in the mid-1990s, evaluations turned to concluding their 'detrimental' impact by the 2000s (Kluve, 2010: 904); such that they were no longer recommended as a legitimate form of activation.

While direct job creation has not completely disappeared, the effect of such evaluation has been to limit its use to specific groups. Reforms have thus limited access to the unskilled and the longer-term unemployed, casting employment through job creation as the most undesirable form of activation and an option to be used as a last resort. In tandem with findings that 'services and sanctions' are most effective (Kluve, 2010: 904), what remains of job creation programmes has also become workfarist in orientation. As such, while job creation still exists, its purpose is removed from its 1980s iteration, posing more as an individualised and punitive test of one's willingness to work and to overcome 'welfare dependency', rather than occupation or inclusion. Germany's One Euro Jobs are emblematic of such reforms. Introduced in 2005, they provide employment at a rate of one or two euros an hour, supplementing welfare payments. Access is limited to those with least employment prospects. Welfare recipients are sanctioned if they refuse a One Euro Job offer, while work is limited to part-time work so that participants can spend the remainder of their working week on job search requirements (Hohmeyer and Wolff, 2010; Harrer and Stockinger, 2021).

\section{Work, unemployment and sustainable welfare without growth}

At this point we put the discussion of activation and the demise of job creation on hold to look at work and unemployment in discussions of eco-social policy. The article therefore moves to terrain where, as mentioned earlier, discussion of activation is absent. However, by engaging with how work and unemployment is addressed in eco-social policy it is possible to consider some potential linkages with some aspects of activation's longer-term history and its more socially oriented treatment of work. In particular, there is perhaps potential to harness the idea of activation as job creation to realise forms of activation within an eco-social policy or sustainable welfare without growth context, in addition to more typical proposals for universal basic income and reduced working time.

To begin with, from the perspective of ecological economics, the problem of unemployment is typically related to unemployment generated by economies without growth. As Martínez-Alier et al. (2010: 1746) explain 'if the economy stops growing but labour productivity does not decline, this would result in growing unemployment'. How to design a 'prosperous way down' (Odum and Odum, 2006) is thus a challenge. From a social perspective, degrowth problematises the fact that we not only live in a growth economy but a growth society, and it is necessary to 'decolonise the growth imaginary' and imagine a 'degrowth society' (Latouche, 2010). The problem of work is tied to the 'ills' of productivism and the contemporary work ethic, which glorifies work and drives people to work harder and longer, reducing life to 'working more, earning more, selling more and buying more' (Demaria et al., 2013: 197).

There is, however, an ambivalence about work within postgrowth perspectives, and this ambivalence has implications for how unemployment is addressed and for how or whether the state would engage with unemployment and pursues active labour market 
policy. As Hoffmann and Paulsen (2020: 348) note, work features prominently in degrowth thinking; yet at the same time, at the level of individual contributions, there is an inconsistency 'in their stance towards work, partly criticising, partly embracing it, or oscillating in between'. Widening this out, degrowth hosts a range of positions on work: from, for example, Hickel's (2020: 4) keenness to clarify that 'degrowth introduces policies to prevent unemployment, and indeed even to improve employment', to Trainer's (2021) view that degrowth represents a 'simpler way' where the notion of employment would eventually become obsolete. These differences also reflect the fact that the broader field of post-work perspectives is not homogenous. Some are characterised as 'classic' anti-work ethic or work-refusal positions that seek liberation from work and the abolition of waged work in favour of autonomous activity and creativity, including the provocation of the right to be idle or to be lazy (Frayne, 2015). Related contributions include the embrace of mass unemployment generated by automation as liberation from work (Srnicek and Williams, 2015) and Pfannebecker and Smith's (2020) questioning of the moralising tendencies of some post-work perspectives that prescribe the good life or what we should do with our time post-work scenarios. The influence of this approach to work can be seen in post-growth's desire to reduce work's relevance in people's lives as much as possible, to blur the line between employment and unemployment and ultimately see an end to both constructs, thus challenging the very idea of active labour market policy and favouring the growth of alternative economies. Working perhaps with a different political temporality and focusing more on the struggles of the 'here and now' (MacLeavy and Lapworth, 2020) and the idea of 'impure politics' (O'Manique et al., 2021), there is also an acknowledgement within post-growth engagements with post-work that it is not realistic to see an end to waged work or employment at least in the near future. Here, the focus is more on the re-working of the role and centrality of paid work versus other forms of work in people's lives, the improvement of conditions of work, and the widening out of work to include socially useful forms of work. In this more 'here and now' perspective it is possible to envisage a role for activation. In what follows these differing emphases and their implications for activation are further teased out.

\section{Between the utopian imaginary and the here and now: work postgrowth and implications for activation}

Broadly, the long-term imaginary of work in post-growth perspectives focuses on autonomy and liberation from work, meaning waged or paid work, with a range of economic alternatives favoured in its place, including self-sufficiency, mutual aid, commoning and the gift economy (Kallis, 2017). This thinking follows a lineage from the precursors of the degrowth movement and the contrasting concepts of heteronomous and autonomous work. These concepts are rooted in Ivan Illich's work on conviviality as a critique of productivism and, of most relevance here, his essay The Right to Useful Unemployment. For Illich heteronomous work is 'done at the behest of a boss', whether that is a corporation or the state. Autonomous work involves the 'creation of value perceived by the worker' (Illich, 1978: 83-84). This is the basis for 'useful unemployment' or convivial work. For Illich reducing the hours of heteronomous work would not do, work would still be dominated by either the market or the state. A shift from industrial society and 
dependence on commodities would mean 'convivial austerity' (Illich, 1978: 36). In these conditions, time spent working might not necessarily decline, but that time would be spent differently, on local, small-scale activity of use to one's self and one's community rather than on the generation of profit. This re-imagining of work has strong connections with post-growth's ideal of alternative economies and economic activity, and any form of activation in this line of reasoning might accordingly be seen as the imposition of heteronomous work.

In a similar vein and drawing on Ilich's conceptions of autonomous and heteronomous work, Gorz, who also is credited with being the originator of the term degrowth (D'Alisa et al., 2014a), outlined the contradictions between the intensification of the work ethic and the growing insecurity of work. Chiming with critiques of the contemporary work ethic and reality of work for many people, he argued that 'a new system has been established which is abolishing 'work' on a massive scale. It is restoring the worst forms of domination, subjugation and exploitation by forcing each to fight against all in order to obtain the 'work' it is abolishing. It is not this abolition we should object to, but its claiming to perpetuate that same work, the norms, dignity and availability of which it is abolishing, as an obligation, as a norm, and as the irreplaceable foundation of the rights and dignity of all' (Gorz, 1999: 1). Gorz sought a release from wage-based work, yet at the same time he recognised that a degree of heteronomous work is necessary because of the 'quantity and diversity of knowledge and techniques' (Gorz, 1985: 50) required in contemporary work contexts, and he did not see heteronomous work as an experience of total alienation. His ideal rather was to see autonomous work, guided by an eco-social rationality, come to dominate the economic rationality of heteronomous work (Bowring, 1996; Gollain, 2016). This rows back from the emphasis on work as self-sufficient and communal activity as the eventual ideal emphasised by the contemporary degrowth movement (Gollain, 2016). Gorz was keen rather to see necessary work take up a limited amount of time, whilst the facilitation of autonomous activity would be enhanced principally by reductions to the working week and by an unconditional income for living'; strategies which he discusses extensively in Farewell to the Working Class (Gorz, 1999). Over time, Gorz also changed his position on the link between work and basic income, initially seeing value in maintaining a link between income and work in recognition of the 'universal social obligation to work', while later arguing that an adequate basic income should allow people to refuse work and engage in self-defined productive activities (Bowring, 2005: 139). In terms of contemporary degrowth policies, these chime with the proposals that are most frequently advocated - namely, work time reduction and universal basic income (Kallis, 2017). They are also advocated alongside an appreciation of the refusal of work and the 'right to idleness' (D'Alisa et al., 2014b: 217). This is not only about the rejection of paid work and waged labour but forging the conditions for realising alternative forms of work or convivial work as a response to the contemporary work ethic. While we can see elements of a more 'mixed' approach to work in Gorz's thinking, his emphasis, and that of the contemporary degrowth movement, is on reducing heteronomous work. Correspondingly, through proposals for universal basic income and reduced working time, the focus tilts towards negating the role of paid work as much as possible. In this context it is difficult to envisage a role for activation that would not simply be perceived as an instrument to normalise and sanctify heteronomous work. 


\section{A role for activation?}

The challenge is thus to think about whether any form of active labour is compatible with work post-growth; about whether it can promote anything other than the contemporary productivist work-ethic and whether it can forge experiences of work that are less heteronomous and more autonomous. Other contributions to the work debate within post-growth allow us to see more substantively how work in the present needs to be improved besides by reducing it. These combine elements of thinking about convivial work, but also crucially lean more towards the idea that many of the qualities of work as employment are significant and the challenge is to change our contemporary work ethic and imagine a different work ethic that improves work. This involves articulating ways in which work, both paid and unpaid, could be changed in a postgrowth context. In this context it is possible to envisage a role for activation and how it might contribute to improving the experience of work and promoting 'good' work that is not exclusive to autonomous or unpaid work.

Jackson (2021) takes inspiration from Hannah Arendt to outline the significance of work to the human condition and its vital social significance: 'good' work challenges us, enhances our creativity and reminds us that being human is our involvement in the collective endeavour of looking after ourselves, and doing work that matters to society. Another precursor to the postgrowth movement can be hailed here - namely, Schumacher and his essays published posthumously as Good Work (Schumacher, 1979). Not unlike Illich's concept of convivial work, he argued that humans need 'good work' for development and focused on local economies providing local goods for local needs with 'intermediate technology' that is user friendly, inclusive and affords workers dignity while being ecologically sustainable. Another contribution comes from Barca's (2019a, b) eco-socialist engagement with postgrowth and the necessity of 'liberation for work'. This focuses on the working class and the problematic ways in which productive and environmental interests have been pitted against each other. Recognising that 'wage work is not going to go away anytime soon' (Barca, 2019a: 175), she suggests that postgrowth perspectives need to expand beyond 'an ecologically minded global middle class willing to reduce consumerism and work-addiction' to include working class interests and the cultivation of an ecological class consciousness (Barca, 2019b: 214). Amongst other things this would involve strengthening the links between work, sustainability and climate justice.

In practical terms these discussions again involve proposals related to basic income and reduced work time, but also more substantively work-focused proposals involving a job guarantee. A core element of universal basic income from this perspective is that it enables socially useful work. For Mair et al. (2020), universal basic income would enhance both people's ability to do socially useful work and improve work conditions. A key feature is its lack of coercion. It allows people to refuse work they do not want to do, but also allows people to positively choose work that contributes to the social good, which they actually want to do, but are sometimes forced out of because of poor pay, such as care work (Jackson, 2021). Such a proposal also connects with proposals concerning temporal autonomy - namely, forms of income support and work reduction tailored to people's needs over the life-course in ways that promote postgrowth forms of sustainable working lives and 'mixed work' involving 'paid work, community work, caring and family work, and self-providing/self-educating work' (Littig, 2018: 574). Pullinger (2014) outlines 
numerous options for working time reduction that involve time rights to variously reduce the working week, the working year and work over one's lifetime (see also Kallis et al., 2013). From a postgrowth perspective the point of such working time reduction initiatives is not that they simply numerically reduce the amount of time spent working but that they are embedded in a project to re-orient economies to the "reproductive" values of ecological and emotional labour' (Fitzpatrick, 2004: 215).

What is particularly distinct about this more 'here and now' perspective to work postgrowth is a growing interest in the role of a job guarantee, which stands to complement the role of universal basic income and reduced working time to facilitate better work postgrowth. Arguments for a job guarantee stem from both a concern with the political viability of the post-growth agenda and the need to engage with contemporary working conditions. Joutsenvirta (2016: 128 in O'Manique et al., 2021: 255) notes the 'wide gap that exists between [degrowth's] normative ideas and analysis about how to bring these ideas from outside the cultural norm into mainstream thinking and practices'. Working with the 'here and now' there is an awareness of the need to recognise 'our complex entanglements with the very systems we are seeking to transform (such as growth-based capitalism), and sees transformative change as a process that moves through these systems rather than trying to escape them' (O'Manique et al., 2021: 257). In this more 'pragmatic' context an argument can be made for engagement with activation through the role of a job guarantee.

To date however, there has been limited debate on the place of job guarantees within post-growth thinking. Principally, Alcott (2013) suggests that employment should be moved from a matter of economics, to being a political right, with a focus on the just distribution of employment, thus avoiding that risk that degrowth's ecological and social goals would be sacrificed by the need for employment. However, he assumes that an income guarantee, in the form of basic income, would still be available. In this sense instituting a job guarantee would provide a right to work but also, in the context of a complementary income policy, a right not to work, thus avoiding the problem with the right to work becoming a norm by which all adults are judged and risk stigma for not working (Graby, 2015). In a similar vein to existing arguments for universal basic income, it would allow people to engage in fully autonomous work if they so choose. However, the offer of a job guarantee addresses the desire to have a job based on the individual and social values of producing and earning, socially embedded and with some sense of individual achievement and contributing to society' (Alcott, 2013: 56). Besides pragmatic grounds, Alcott outlines several other gains to be had by a postgrowth version of a job guarantee: from an individual point it removes insecurity and affords workers the right to refuse undesirable employment. In this context a job guarantee allows government to not just address the quantity but also quality of employment (Unti, 2018). Elaborating on this point, Unti (2018: 75-76) suggests that the 'real promise of the job guarantee lies in its potential for transforming the quality of work. ... freed from the profit constraint, a job guarantee opens possibilities for all kinds of improvements in working conditions, hours of work and types of paid employment'.

From a societal point of view there is the potential to tailor the employment offered to socially and ecologically useful goods and services, echoing Schumacher's (1979) vision of 'good work'. There is a clear synergy here with how welfare needs to be re-imagined postgrowth to involve services that are local, relational and preventive, but which also entail more meaningful work provision (Walker et al., 2021). It would also potentially 
privilege work in the 'maintenance economy' (Dengler and Strunk, 2018), or the 'slow sector' (Jackson, 2021). Here work takes time and takes care of both people and the planet; types of work which the Covid-19 pandemic revealed as vitally important but under-valued. From an economic point of view Unti (2018: 69) sees the value of a postgrowth form of job guarantee because 'it severs the link between aggregate demand and employment'. In other words, it is not dependent on growth. Work in the slow sector which involves low productivity is thus not a problem but welcome. This in turn dovetails with the more radical arguments and vision for eco-taxes from a degrowth perspective that focus on capital (rather than shifting solely from labour to environmental 'bads' such as carbon). This includes targeting advertising and finance (Kallis and March, 2015) which is tied to 'disaccumulating capital'. This would also be facilitated by setting maximum incomes and wealth taxes that dampen the accumulative impulse of capitalism and focuses instead on socially useful work and production (Hickel, 2021).

This then circles back to the presence of job creation in existing activation policy, which as discussed earlier, has not disappeared but is negatively appraised by conventional economics. Moreover, it functions in a most punitive way in many schemes. This of course is contrary to any form of work envisaged for postgrowth societies in the long or short term. There are no grounds for defending the coercive, work-first, precarious employment generating machine activation has become. However, there is still perhaps the kernel of potential in some elements of job creation that give substance to thinking about how activation could positively contribute. As such it potentially offers possibilities for looking at how we start where we are, given the blockades to achieving eco-social change (Fitzpatrick, 2021).

Stamm et al. (2020) note that there are already examples across Europe of activation involving what they call 'eco-social innovation' that support local communities, co-operatives, and are of clear holistic benefit to participants, their communities and the environment. These include grass-roots projects, local co-operatives and social enterprises involving activities such as community supported agriculture and organic food, community arts and the promotion of bike culture. Crucially however, their existence and development depend on the provision of social security and activation programmes that allow people who are unemployed to participate. Yet many projects are subject to 'unreliable and fragile supports' and participants face welfare conditions that block their long-term participation and wishes (Stamm et al., 2020: 51). Moreover, their eco-social value is unrecognised. Strikingly, in the case of Finnish projects discussed, Stamm et al. (2020: 47) remark that people who participated 'lived in a paradoxical situation since they were fully occupied in creating the activities in [eco-social innovations] but in the eyes of the welfare institutions, they were categorized as unemployed or marginalized poor people'.

Similar points can be made about Ireland's community employment programme which continues as somewhat of an outlier in the overall decline of job creation across Europe. Embedded in local not-for-profit organisations and focused on social inclusion, it remains a substantial part of Ireland's activation repertoire. Though frequently castigated for its poor labour market outcomes and not without problems in its design; it is of value to participants and to communities for the types of work and services provided. Petautschnig Arancibia (2021) describes the positive experiences of participants regaining a sense of autonomy, and the beneficial effects of co-producing their work based on their preferences and of helping others. Such projects are potential examples of how activation could 
contribute to both the reduction, just distribution and improvement of work postgrowth. Their re-design and re-valuing for eco-social purposes through a job-guarantee would forge synergistic connections between welfare and local grassroots economic activities and indeed blur the lines between heteronomous and autonomous work.

\section{Conclusion}

In brief, this article has attempted to address the fact that activation policy's value and potential as an instrument of eco-social policy is frequently overlooked. By re-valuing activation's role in job creation and linking this to arguments for a job guarantee within post-growth thinking it is possible to envisage ways in which it might contribute to progressing models of sustainable welfare without growth. While advocating for a job-guarantee might seem counter-intuitive in the context of efforts to reduce the centrality of work in post-growth, it does allow the possibility of thinking how work could be transformed and paradoxically be made less central as part of more sustainable and autonomous lives under an eco-social rationality. Moreover, there are concrete examples of how this could work already 'hiding in plain sight' in some European activation systems but which are not recognised or valued for their eco-social potential. This is not to say that they are ready-made technical solutions, but perhaps offer ways in which thinking about how to transition to sustainable welfare without growth are not so unimaginable and impossible.

\section{Acknowledgements}

My thanks to the guest editors and anonymous reviewers for their helpful comments and guidance on this article.

\section{References}

Aigner, E., Baratech Sanchez, L., Bernhardt, D., Curnow, B., Hödl, C. Leonhardt, H. and Luo, A. (2016) Sustainable Work: Seven Case Studies on Social-Ecological Implications in Europe, WWWforEurope Working Paper, No. 112, Vienna: WWWforEurope.

Alcott, B. (2013) 'Should degrowth embrace the job guarantee?', Journal of Cleaner Production, 38, 56-60. Barca, S. (2019a) 'An alternative worth fighting for: degrowth and the liberation of work', in E. Chertkovskaya, A. Paulsson and S. Barca (eds.), Towards a Political Economy of Degrowth, London: Rowman Littlefield, 175-92.

Barca, S. (2019b) 'The labor(s) of degrowth', Capitalism Nature Socialism, 30, 2, 207-16.

Bonoli, G. (2011) 'Active labour market in a changing economic context', in J. Clasen and D. Clegg (eds.), Regulating the Risk of Unemployment National Adaptations to Post-Industrial Labour Markets in Europe, Oxford: Oxford University Press, 318-32.

Bowring, F. (1996) 'Misreading Gorz', New Left Review, 217, May-June, 102-22.

Bowring, F. (2005) 'André Gorz: autonomy and equity in the post-industrial age', The Sociological Review, $53,1,134-47$.

D'Alisa, G., Demaria, F. and Kallis, G. (eds.) (2014a) Degrowth: A Vocabulary for a New Era, London: Routledge

D'Alisa, G., Demaria, F. and Kallis, G. (2014b) 'From austerity to dépense', in G. D'Alisa, F. Demaria and G. Kallis (eds.) Degrowth: A Vocabulary for a New Era, London: Routledge, 215-20. 
Demaria, F., Schneider, F., Sekulova, F. and Martinéz-Alier, J. (2013) 'What is degrowth? From an activist slogan to a social movement', Environmental Values, 22, 13, 191-215.

Dengler, C. and Strunk, B. (2018) 'The monetised economy versus care and the environment: degrowth perspectives on reconciling an antagonism', Feminist Economics, 24, 3, 160-83.

Dengler, K. (2015) 'Effectiveness of sequences of One-Euro-Jobs for welfare recipients in Germany', Applied Economics, 47, 6170-90.

Fitzpatrick, T. (2004) 'Social policy and time', Time and Society, 13, 2/3, 197-219.

Fitzpatrick, T. (2021) 'Paradigm lost? Blocking the path to ecosocial welfare and post-productivism', in C. Deeming (ed.), The Struggle for Social Sustainability, Bristol: Policy Press, 129-49.

Frayne, D. (2015) The Refusal of Work: The Theory and Practice of Resistance to Work, London: Zed Books.

Gollain, F. (2016) 'André Gorz: wage labour, free time and ecological reconstruction', Green Letters, 20, 2, 127-39.

Gorz, A. (1985) Paths to Paradise, London: Malcolm Imrie.

Gorz, A. (1999) Reclaiming Work, Cambridge: Polity.

Gough, I. (2017) Heat, Greed and Need: Climate Change, Capitalism and Sustainable Wellbeing, Cheltenham: Edward Elgar.

Graby, S. (2015) 'Access to or liberation from work? Disabled people, autonomy and post-work politics', Canadian Journal of Disability Studies, 4, 2, 132-60.

Harrer, T. and Stockinger, B. (2021) 'First step and last resort: One-Euro Jobs after the reform', Journal of Social Policy, DOI: doi.org/10.1017/S0047279421000313.

Hickel, J. (2020) 'What does degrowth mean? A few points of clarification', Globalizations, DOI: doi.org/ 10.1080/14747731.2020.1812222.

Hickel, J. (2021) 'Going out of the crisis, we can have a recovery without growth', iD4D Sustainable Development News, https://ideas4development.org/en/growth-capitalism-crisis-ecology/ [accessed 26.10.2021].

Hoffmann, M. and Paulsen, R. (2020) 'Resolving the 'jobs-environment dilemma'? The case for critiques of work in sustainability research', Environmental Sociology, 6, 4, 343-54.

Hohmeyer, K. and Wolff, J. (2010) 'Direct job creation revisited: is it effective for welfare recipients and does it matter whether participants receive a wage?', IAB-Discussion Paper, 21/2010, Nürnberg: IAB.

Illich, I. (1978) The Right to Useful Unemployment, London: Marion Boyars.

Jackson, T. (2021) Postgrowth: Life after Capitalism, Cambridge: Polity.

Kallis, G. (2017) 'Economics without growth', in M. Castells (ed.), Another Economy is Possible: Culture and Economy in a Time of Crisis, Cambridge: Polity, 34-54.

Kallis, G., Kalush, M., O'Flynn, H., Rossiter, J. and Ashford, N. (2013) 'Friday off: reducing working hours in Europe', Sustainability, 5, 4, 1545-67.

Kallis, G. and March, H. (2015) 'Imaginaries of hope: the utopianism of degrowth', Annals of the Association of American Geographers, 105, 2, 360-8.

Kluve, J. (2010) 'The effectiveness of European active labour market programmes', Labour Economics, 17, 6, 904-18.

Koch, M. (2018) 'Sustainable welfare, degrowth and eco-social policies in Europe', in B. Vanhercke, D. Ghailani and S. Sabato (eds.), Social Policy in the European Union: State of Play 2018, Brussels: ETUI, 35-50.

Latouche, S. (2010) 'Degrowth', Journal of Cleaner Production, 18, 6, 519-22.

Littig, B. (2018) 'Good work? Sustainable work and sustainable development: a critical gender perspective from the Global North', Globalizations, 15, 4, 565-79.

MacLeavy, J. and Lapworth, A. (2020) 'A 'post-work' world: geographical engagements with the future of work', Political Quarterly, 91, 2, 310-16.

Mair, S., Druckman, A. and Jackson, T. (2020) 'A tale of two utopias: work in a postgrowth world', Ecological Economics, 173, 1-11. 
Martínez-Alier, J., Pascual, U., Vivien, F-D. and Zaccai, E. (2010) 'Sustainable degrowth: mapping the context, criticisms and future prospects of an emergent paradigm', Ecological Economics, 69, 9, 1741-7.

O'Manique, C., Rowe, J. and Shaw, K. (2021) 'Degrowth, political acceptability and the Green New Deal', Journal of Human Rights and the Environment, 12, 2, 253-76.

Odum, H. and Odum, E. (2006) 'The prosperous way down', Energy, 31, 1, 21-32.

OECD (1994) The OECD Jobs Study, Facts, Analysis, Strategies, Paris: OECD.

Petautschnig Arancibia, C. P. (2021) The Self at Work: Understanding the Experience of Community Placement in Activation Schemes in a Post-Recession Context, Thesis, Trinity College Dublin: School of Social Work and Social Policy.

Pettinger, L. (2019) What's Wrong with Work?, Bristol: Policy Press.

Pfannebecker, M. and Smith, J. A. (2020) Work Want Work Labour and Desire at the End of Capitalism, London: Zed Books.

Pullinger, M. (2014) 'Working time reduction policy in a sustainable economy: criteria and options for its design', Ecological Economics, 103, July 2014, 11-19.

Sage, D. (2019) 'Unemployment, wellbeing and the power of the work ethic: implications for social policy', Critical Social Policy, 39, 2, 205-28.

Schumacher, E. F. (1979) Good Work, London: Harpercollins.

Srnicek, N. and Williams, A. (2015) Inventing the Future: Postcapitalism and a World Without Work, London: Verso.

Stamm, I., Matthies, A-L., Hirvilammi, T. and Närhi, K. (2020) 'Combining labour market and unemployment policies with environmental sustainability? A cross-national study on ecosocial innovations', Journal of International and Comparative Social Policy, 36, 1, 42-56.

Standing, G. (2011) The Precariat. The New Dangerous Class, London: Bloomsbury.

Trainer, T. (2021) 'What does Degrowth mean? Some comments on Jason Hickel's "A few points of clarification"', Globalizations, 18, 7, 1112-6.

Unti, B. J. (2018) 'The job guarantee and transformational degrowth', in M. Murray and M. Forstater (eds.), Full Employment and Social Justice, London: Palgrave Macmillan, 63-82.

Walker, C. C., Druckman, A. and Jackson, T. (2021) 'Welfare systems without economic growth: a review of the challenges and next steps for the field', Ecological Economics, 186, 107066.

Weishaupt, J. T. (2013) 'Origin and genesis of activation policies in 'Old' Europe: towards a balanced approach?', in I. Marx and K. Nelson (eds.), Minimum Income Protection in Flux, London: Palgrave Macmillan, 190-216.

Wiese, K. and Mayrhofer, J. (2020) Escaping the Growth and Jobs Treadmill, A New Policy Agenda for Post-Corona Virus Europe, Brussels: EYF and EEB. 